\title{
Economic Dispatch untuk Sistem Kelistrikan Microgrid dengan Energy Storage berbasis Adaptive Particle Swarm Optimization
}

\author{
Nugroho Wicaksono, Heri Suryoatmojo, dan Rony Seto Wibowo \\ Jurusan Teknik Elektro, Fakultas Teknologi Industri, Institut Teknologi Sepuluh Nopember (ITS) \\ Jl. Arief Rahman Hakim, Surabaya 60111 \\ E-mail: gmnugrohowicaksono@gmail.com, suryomgt@ee.its.ac.id, ronyseto@ee.its.ac.id
}

\begin{abstract}
Abstrak-Perkembangan ilmu pengetahuan dan teknologi membawa pengaruh akan meningkatnya kebutuhan akan daya listrik, namun ketersediaan sumber energi konvensional (fossil) semakin menipis yang tentunya akan berdampak pada tingkat ketahanan listrik. Oleh karenanya diperlukan pembangkitpembangkit tersebar berskala kecil (microgrid). Pembangkit tersebar ini diupayakan bersumber pada energi terbarukan dengan meminimalkan pemakaian dari sumber energi konvensional serta digunakan energy storage untuk power balance. Oleh karena adanya microgrid ini maka penting untuk menentukan besarnya pembangkitan daya listrik yang optimal dari masing-masing pembangkit dan kapasitas optimal energy storage sehingga kebutuhan daya listrik dapat dipenuhi dengan biaya yang optimal. Pada penelitian ini dilakukan analisis mengenai economic dispatch di dalam pengoperasian sistem kelistrikan microgrid dengan energy storage. Algoritma APSO digunakan untuk memecahkan masalah minimalisasi total biaya sistem. Simulasi komputer menggunakan Matlab dilakukan untuk menunjukkan efektivitas dari metodologi yang diusulkan dan dampak dari harga dan sistem penyimpanan pada economic dispatch.
\end{abstract}

Kata Kunci-Economic Dispatch (ED), Microgrid, Artificial Intelligence, Adaptive Particle Swarm Optimization, Energy Storage.

\section{Pendahuluan}

$\mathrm{T}$ TENAGA listrik dapat dikatakan telah menjadi kebutuhan primer bagi kehidupan manusia saat ini. Seiring dengan pertumbuhan ekonomi dan infrastruktur, permintaan terhadap daya listrik pun terus bertambah [1]. Namun peningkatan kebutuhan tenaga listrik ini tidak dapat secara langsung diatasi dengan menambah pasokan daya dari pembangkit tanpa memperhatikan biaya dan kemampuan dari masing-masing pembangkit yang digunakan.

Electric Power System (EPS) pun telah mengalami perubahan yang signifikan. Perubahan ini dikombinasikan dengan kecenderungan untuk produksi yang efisien dan memberikan dampak lingkungan yang semakin baik, mengarahkan untuk mencari sumber energi alternatif baru untuk pembangkit listrik.

Salah satu efek dengan adanya perubahan terhadap EPS adalah adanya pembangkit tersebar (distributed generation). Hal ini menciptakan konsep baru terkait dengan peningkatan penggunaan sumber energi baru - terbarukan, memperkenalkan ide microgrid [2]. Microgrid didefinisikan sebagai bagian dari sistem distribusi dan struktur dasarnya terdiri dari sumber energi yang terdistribusi, perangkat penyimpanan dan beban yang berubah-ubah. Sistem ini dapat dioperasikan dengan terhubung ke jala-jala atau dengan metode terisolasi (island-ing mode) [3].

Dengan adanya konsep microgrid dan usaha peningkatan nilai ekonomis dalam pemenuhan kebutuhan beban sistem ini, maka dibutuhkan suatu konsep Economic Dispatch (ED). ED merupakan instrumen yang sangat penting dalam kontrol dan operasi sistem tenaga [4]. ED mempunyai fungsi utama untuk mengatur pembagian beban ke setiap pembangkit untuk dapat memenuhi kebutuhan beban dengan biaya pembangkitan yang paling optimal [5]. Beberapa pembangkit energi listrik yang dimodelkan pada penelitian ini adalah pembangkit sel surya, turbin angin, sel bahan bakar (fuel cell), turbin mikro dan generator diesel serta juga media penyimpanan energi (energy storage). Pembangkit sel surya dan turbin angin merupakan pembangkit dengan sumber energi baru-terbarukan sehingga kebutuhan akan bahan bakar hanya diperlukan untuk pengoperasian pembangkit berbahan bakar [6].

Dalam penelitian ini diusulkan solusi untuk ED dalam sistem kelistrikan microgrid dengan sumber energi baruterbarukan, pembangkit berbahan bakar dan media penyimpanan energi (baterai) dengan menggunakan kecerdasan buatan (artificial intelligence). Artifical intelligence yang digunakan sebagai metode dalam penelitian ini adalah Adaptive Particle Swarm Optimization (APSO).

\section{DASAR TEORI}

\section{A. Sistem Kelistrikan Microgrid}

Beberapa pembangkit yang digunakan dalam sistem kelistrikan microgrid diantaranya pembangkit berbahan bakar serta pembangkit dengan sumber energi baru-terbarukan dan juga media penyimpanan energi. Dengan menggunakan pembangkit tersebar berskala kecil, daya listrik dibangkitkan dekat dengan beban untuk meningkatkan keandalan dan mengurangi rugi-rugi jaringan. Terdapat dua mode operasi dalam sistem kelistrikan microgrid yaitu islanded dan gridconected.

Pada penelitian ini, tipe mode operasi sistem kelistrikan microgrid yang digunakan adalah islanded. Dengan tipe operasi ini pembangkit yang ada beroperasi secara mandiri untuk memenuhi kebutuhan sistem yang ada. Beberapa sumber energi listrik yang dimodelkan dalam sistem microgrid ini yakni sel surya dan turbin angin dengan kapasitas rating masing-masing $25 \mathrm{~kW}$ dan $20 \mathrm{~kW}$, sel bahan bakar (fuel cell) 
$25 \mathrm{~kW}$, turbin mikro $75 \mathrm{~kW}$ dan generator diesel $50 \mathrm{~kW}$ dan baterai dengan kapasitas maksimal charge-discharge $30 \mathrm{~kW}$ seperti yang ditampilkan pada gambar 1 . Pemodelan sistem kelistrikan microgrid ini mendekati kondisi nyata sistem kelistrikan di pulau-pulau terpencil dimana tidak mendapatkan suplai daya dari jala-jala PLN.

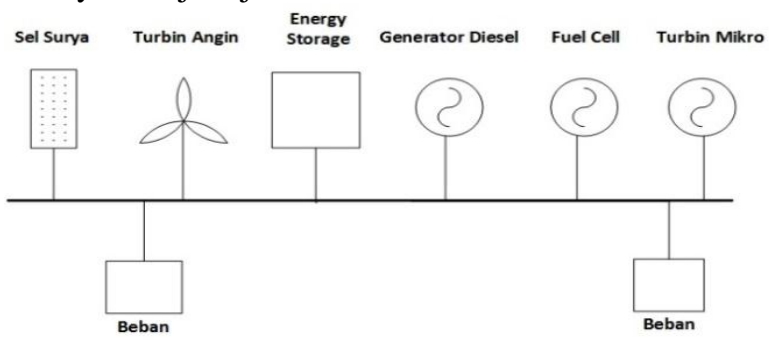

Gambar 1. Sistem Kelistrikan Microgrid

\section{B. Sel Surya}

Daya keluaran dari modul sel surya dapat dihitung dengan menggunakan persamaan:

$P p v=M\left(P s t c \frac{G a c t}{G s t c}(1+k(T c-T r))\right)$

dimana Ppv dan Pstc adalah daya keluaran dari modul sel surya saat radiasi Gact (W) dan saat STC (W), Gact dan Gstc adalah radiasi aktual $\left(\mathrm{W} / \mathrm{m}^{2}\right)$ dan radiasi saat STC (1000 $\mathrm{W} / \mathrm{m}^{2}$ ), $\mathrm{M}$ adalah jumlah modul sel surya, $\mathrm{k}$ adalah koefisien suhu untuk daya modul $(\% / \mathrm{C})$, Tc dan $\mathrm{Tr}$ adalah suhu sel $\left({ }^{\circ} \mathrm{C}\right)$ dan referensi $\left(25^{\circ} \mathrm{C}\right)$.

Modul sel surya yang digunakan pada penelitian ini adalah SOLAREX MSX-83 sebanyak 302 modul, dimana modul sel surya ini memiliki karakteristik yaitu [6]:

Daya maksimum saat STC (Pstc) $=83$, tegangan saat daya maksimum $=17.1 \mathrm{~V}$, arus saat daya maksimum $=4.85 \mathrm{~A}$, arus short circuit saat STC $=5.27 \mathrm{~A}$, tegangan open circuit saat $\mathrm{STC}=21.2 \mathrm{~V}$, koefisien suhu untuk daya $(\mathrm{k})=-0.5$

\section{Turbin Angin}

Pada penelitian ini digunakan turbin angin ReDriven $20 \mathrm{~kW}$ sebanyak 2 unit. Didapatkan persamaan seperti berikut:
Pwt $=0$,
Vact $<$ Vci
$P w t=a \cdot V a c t^{3}+b \cdot V a c t^{2}+c \cdot V a c t+d$
$\mathrm{Vci} \leq \mathrm{Vact} \leq \mathrm{Vr}$
Pwt $=22$,
$\mathrm{Vr}<\mathrm{Vact}<\mathrm{Vco}(2)$
Pwt $=0$
$\mathrm{Vact}>\mathrm{Vco}$
Pwt $=$ Pwt $\times$ J

dimana Pwt dan Pwt,r adalah daya keluaran dari WT $(\mathrm{kW})$ dan rating daya WT $(\mathrm{kW})$, J adalah jumlah WT yang terpasang (unit), Vci dan Vco adalah kecepatan cut-in $(\mathrm{m} / \mathrm{s})$ dan cut-out $(\mathrm{m} / \mathrm{s}), \mathrm{Vr}$ dan Vact adalah rating kecepatan angin $(\mathrm{m} / \mathrm{s})$ dan kecepatan angin aktual $(\mathrm{m} / \mathrm{s})$.

Parameter yang digunakan pada penelitian ini adalah:

$\mathrm{a}=-0.0196, \mathrm{~b}=0.5874, \mathrm{c}=-2.6814, \mathrm{~d}=4.0076$, Pwt, $\mathrm{r}=20$

$\mathrm{kW}, \mathrm{Vr}=11 \mathrm{~m} / \mathrm{s}, \mathrm{Vci}=2 \mathrm{~m} / \mathrm{s}, \mathrm{Vco}=18 \mathrm{~m} / \mathrm{s}$.

\section{D.Baterai (Energy Storage)}

Pada penelitian ini baterai yang digunakan memiliki koefisien biaya 0.0043\$/kWh [12]. Dengan menggunakan kurs dollar-euro per tanggal 24 April 2016 maka didapatkan koefisien biaya baterai adalah $0.003831 € / \mathrm{kWh}$. Kapasitas maksimal yang dapat disimpan oleh baterai adalah $300 \mathrm{kWh}$ dengan SOC minimum baterai $60 \mathrm{kWh}$. Baterai ini juga memiliki kapasitas maksimal daya yang dapat di chargedischarge sebesar $30 \mathrm{~kW}$ [12].

Baterai yang digunakan pada simulasi ini beroperasi pada kemampuan daya maksimal charge-discharge-nya yakni 30 kW tanpa mempertimbangkan berapa daya yang sudah tersimpan atau terpakai sebelumnya pada baterai.

Ketika kondisi beban microgrid lebih kecil dari total pembangkitan oleh pembangkit energi baru-terbarukan maka daya yang disimpan ke dalam baterai dimodelkan:

Prenew $=\mathrm{Ppv}+\mathrm{Pwt}$

Pbatt $=$ Prenew - Beban

dimana Ppv dan Pwt adalah daya terbangkitkan oleh pembangkit sel surya dan turbin angin $(\mathrm{kW})$, Prenew adalah total daya terbangkitkan oleh pembangkit energi baruterbarukan $(\mathrm{kW})$, Beban adalah total kebutuhan daya sistem $(\mathrm{kW})$, Pbatt adalah daya yang disimpan dalam baterai $(\mathrm{kW})$.

Sedangkan ketika kondisi beban microgrid lebih besar dari total pembangkitan oleh pembangkit energi baru-terbarukan maka daya dari baterai akan digunakan untuk memenuhi kebutuhan beban sistem sebagai berikut:

Prenew $=\mathrm{Ppv}+\mathrm{Pwt}$

Pbatt $=$ Load - Prenew

dimana Ppv dan Pwt adalah daya terbangkitkan oleh pembangkit sel surya $(\mathrm{kW})$ dan turbin angin $(\mathrm{kW})$, Prenew adalah total daya terbangkitkan oleh pembangkit energi baruterbarukan $(\mathrm{kW})$, Load adalah total kebutuhan daya sistem $(\mathrm{kW})$, Pbatt adalah daya yang digunakan dari baterai $(\mathrm{kW})$.

\section{E. Sel Bahan Bakar (Fuel Cell)}

Biaya operasi untuk sel bahan bakar sebagai berikut: $F(P f c)=\mathrm{a}+\mathrm{b} . P f c+$ c. $P f c^{2}$ dimana $\mathrm{F}(\mathrm{Pfc})$ adalah total biaya operasi sel bahan bakar $(€ / \mathrm{h})$, a, b, c adalah koefisien biaya sel bahan bakar. Pfc adalah keluaran daya dari sel bahan bakar $(\mathrm{kW})$.

Pada penelitian ini digunakan sel bahan bakar dengan daya output maksimal $25 \mathrm{~kW}$ dengan koefisien bahan bakar [13]: $\mathrm{a}=12, \mathrm{~b}=45, \mathrm{c}=0.01$

\section{F. Turbin Mikro}

Biaya operasi dari turbin mikro ini dapat dimodelkan dengan polinomial kuadrat. Biaya operasi untuk turbin mikro sebagai berikut:

$F(P t m)=\mathrm{a}+$ b. Ptm + c. Ptm ${ }^{2}$

dimana $\mathrm{F}(\mathrm{Ptm})$ adalah total biaya operasi turbin mikro $(€ / \mathrm{h})$, a, b, c adalah koefisien biaya turbin mikro, Ptm adalah keluaran daya dari turbin mikro $(\mathrm{kW})$.

Pada penelitian digunakan turbin mikro dengan daya output maksimal $75 \mathrm{~kW}$ dengan koefisien bahan bakar [13]:

$\mathrm{a}=12, \mathrm{~b}=48, \mathrm{c}=0.01$

\section{G.Generator Diesel}

Biaya operasi dari generator diesel ini dapat dimodelkan dengan polinomial kuadrat. Biaya operasi untuk generator diesel sebagai berikut:

$F(P d g)=\mathrm{a}+\mathrm{b} \cdot \mathrm{Pdg}+\mathrm{c} \cdot P d g^{2}$

dimana $\mathrm{F}(\mathrm{Pdg})$ adalah total biaya operasi generator diesel $(€ / \mathrm{h}), \mathrm{a}, \mathrm{b}, \mathrm{c}$ adalah koefisien biaya generator diesel, Pdg adalah keluaran daya dari generator diesel $(\mathrm{kW})$. 
Pada penelitian ini digunakan generator diesel dengan daya output maksimal $50 \mathrm{~kW}$ dan memiliki koefisien bahan bakar [13]:

$\mathrm{a}=10, \mathrm{~b}=40, \mathrm{c}=0.01$

\section{ECONOMIC DISPATCH}

Economic Dispatch (ED) merupakan suatu teknik yang digunakan untuk membagi daya yang dibangkitkan oleh setiap pembangkit pada kondisi beban tertentu. Pembagian daya yang dibangkitkan oleh pembangkit bertujuan untuk mendapatkan biaya pembangkitkan yang paling ekonomis. ED tidak memperhatikan batas ramp rate sehingga tidak dapat digunakan untuk memenuhi kebutuhan beban dalam rentang waktu tertentu. Fungsi total biaya dari setiap generator unit-i dimodelkan dengan persamaaan polinomial kuadrat yang dirumuskan sebagai berikut:

$C F(P)=\sum_{n=1}^{i} \operatorname{Cix} F i(P i)$

$F i(P i)=\left(a_{i}+b_{i} \cdot \mathrm{Pi}+c_{i} \cdot P i^{2}\right)$

dimana Fi adalah biaya pembangkitan pada pembangkit unit-i, $\mathrm{Pi}$ adalah daya output dari pembangkit unit-i, $\mathrm{Ci}$ adalah biaya bahan bakar pada pembangkit unit-i, ai,bi,ci adalah koefisien biaya dari generator ke-i.

Sistem microgrid yang digunakan pada penelitian ini menggunakan dua jenis pembangkit energi baru-terbarukan dan tiga jenis pembangkit berbahan bakar serta satu jenis energy storage. Selain ketiga pembangkit berbahan bakar tersebut, baterai sebagai media penyimpanan energi juga memerlukan biaya dalam pengoperasiannya. Biaya operasi dari baterai ini didapatkan berdasarkan biaya saat investasi pembelian dan perawatan. Sehingga didapatkan fungsi biaya total operasi dari keseluruhan pembangkit tersebut adalah:

$\mathrm{CF}(\mathrm{P})=\mathrm{CF}\left(\mathrm{P}_{\text {batt }}\right)+\mathrm{CF}\left(\mathrm{P}_{\mathrm{FC}}\right)+\mathrm{CF}\left(\mathrm{P}_{\mathrm{MT}}\right)+\mathrm{CF}\left(\mathrm{P}_{\mathrm{DG}}\right)$.

dimana $\mathrm{CF}\left(\mathrm{P}_{\text {batt }}\right), \mathrm{CF}\left(\mathrm{P}_{\mathrm{FC}}\right), \mathrm{CF}\left(\mathrm{P}_{\mathrm{MT}}\right), \mathrm{CF}\left(\mathrm{P}_{\mathrm{DG}}\right)$ dan $\mathrm{CF}(\mathrm{P})$ masing-masing adalah total biaya operasi baterai, pembangkit sel bahan bakar, pembangkit turbin mikro, pembangkit generator diesel dan total biaya operasi keseluruhan pembangkit $(€ / \mathrm{h})$.

Berdasarkan penjelasan pada sub-bab sebelumnya, maka parameter fungsi biaya yang digunakan dalam penelitian ini adalah:

Tabel 1.

Data Koefisien Harga Pembangkit

\begin{tabular}{ccccc}
\hline \hline Koefisien & Sel Bahan Bakar & $\begin{array}{c}\text { Turbin } \\
\text { Mikro }\end{array}$ & $\begin{array}{c}\text { Generator } \\
\text { Diesel }\end{array}$ & Baterai \\
\hline $\mathrm{a}$ & 0.01 & 0.01 & 0.01 & \\
$\mathrm{~b}$ & 45 & 48 & 40 & 0.003831 \\
$\mathrm{c}$ & 12 & 12 & 10 & \\
\hline \hline
\end{tabular}

Sehingga grafik perbandingan biaya operasi dari keseluruhan pembangkit yang digunakan adalah:

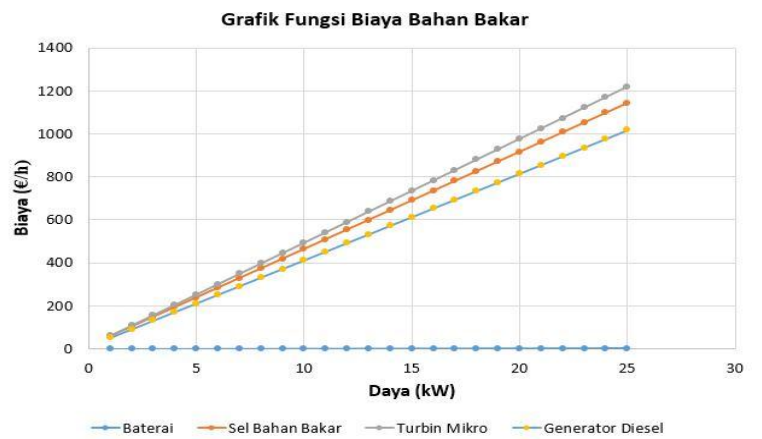

Gambar 2. Grafik Fungsi Biaya Pembangkit Keseluruhan

\section{A. Constraints}

Terdapat beberapa constraint yang perlu dipertimbangkan dalam operasi ED yakni equality dan inequality constraint.

Equality constraint merupakan batasan yang merepresentasikan keseimbangan daya dalam sistem. Karena terdapat dua jenis pembangkit energi baru-terbarukan maka beban daya sistem yang akan dioptimasi oleh ED ini adalah total beban sistem dikurangi daya yang dihasilkan oleh pembangkit energi baru-terbarukan. Fungsi persamaannya dapat dinyatakan sebagai berikut:

Popt $=$ Beban - Prenew .

dimana Popt adalah daya yang dioptimasi oleh pembangkit berbahan bakar dan baterai, Beban adalah besarnya permintaan daya pada sistem, Prenew adalah daya total yang dapat disuplai oleh pembangkit energi baru-terbarukan.

Inequality constraint merupakan batasan yang merepresentasikan kapasitas daya dari pembangkit. Terdapat tiga jenis pembangkit berbahan bakar dalam sistem kelistrikan microgrid yang digunakan dalam penelitian ini. Pembangkit berbahan bakar tersebut mempunyai kapasitas daya maksimum dan minimum yang berbeda-beda. Fungsi pertidaksamaannya adalah sebagai berikut:

$\mathrm{P}_{\mathrm{FC}} \min \leq \mathrm{P}_{\mathrm{FC}} \leq \mathrm{P}_{\mathrm{FC}} \max$

$\mathrm{P}_{\mathrm{MT}} \min \leq \mathrm{P}_{\mathrm{MT}} \leq \mathrm{P}_{\mathrm{MT}} \max$

$\mathrm{P}_{\mathrm{DG}} \min \leq \mathrm{P}_{\mathrm{DG}} \leq \mathrm{P}_{\mathrm{DG}} \max$

$\mathrm{P}_{\text {battcharge }} \min \leq \mathrm{P}_{\text {batt }} \leq \mathrm{P}_{\text {battcharge }} \max$

dimana $\mathrm{P}_{\mathrm{FC}} \min$ dan $\mathrm{P}_{\mathrm{FC}} \max$ adalah pembangkitan daya minimum dan maksimum dari pembangkit sel bahan bakar, $\mathrm{P}_{\mathrm{MT}}$ min dan $\mathrm{P}_{\mathrm{MT}}$ max adalah pembangkitan daya minimum dan maksimum dari pembangkit turbin mikro, $\mathrm{P}_{\mathrm{DG}} \min$ dan $\mathrm{P}_{\mathrm{DG}} \mathrm{max}$ adalah pembangkitan daya minimum dan maksimum dari pembangkit generator diesel, $\mathrm{P}_{\text {battcharge }} \min$ dan $\mathrm{P}_{\text {battcharge }} \mathrm{max}$ adalah pembangkitan daya minimum dan maksimum dari baterai.

Dalam penelitian ini parameter yang digunakan adalah: $\mathrm{P}_{\mathrm{FC}} \min =5 \mathrm{~kW}, \mathrm{P}_{\mathrm{FC}} \max =75 \mathrm{~kW}, \mathrm{P}_{\mathrm{MT}} \min =5 \mathrm{~kW}, \mathrm{P}_{\mathrm{MT}} \max$ $=25 \mathrm{~kW}, \mathrm{P}_{\mathrm{DG}} \min =5 \mathrm{~kW}, \mathrm{P}_{\mathrm{DG}} \max =50 \mathrm{~kW}, \mathrm{P}_{\text {battcharge }} \min =$ $0 \mathrm{~kW}, \mathrm{P}_{\text {battcharge }} \max =30 \mathrm{~kW}$.

\section{PENERAPAN ADAPTIVE PARTICLE SWARM OPTIMIZATION}

\section{A. Particle Swarm Optimization (PSO)}

Algoritma PSO merupakan salah satu algoritma kecerdasan buatan (artificial intelligence), termasuk ke dalam kategori swarm intelligence yang merupakan algoritma yang terinspirasi oleh perilaku sosial kolektif koloni burung atau 
binatang. Pergerakan burung yang direpresentasikan sebagai pergerakan partikel ditentukan oleh nilai posisi sebelumnya dan nilai kecepatan saat ini. Nilai posisi dari partikel ini yang kemudian merepresentasikan solusi yang mungkin pada kasus optimasi dan nilai kecepatan digunakan untuk update posisi partikel.

Algoritma PSO ini pertama kali diperkenalkan oleh J. Kennedy [9]pada tahun 1995. Algoritma PSO dimulai dengan inisialisasi partikel solusi secara acak. Algoritma PSO akan beriterasi memperbaharui nilai posisi partikel sebagai fungsi dari perubahan kecepatan partikel sampai iterasi maksimal terpenuhi. Output dari hasil iterasi algoritma PSO ini didapatkan hasil nilai optimasi. Persamaan update rulenya:

$\mathrm{V}_{\mathrm{it}}=\mathrm{V}_{\mathrm{it}-1}+\mathrm{C}_{1} \cdot$ rand. $\left(\right.$ Pbest $\left._{\mathrm{it}}-\mathrm{X}_{\mathrm{it}-1}\right)+\mathrm{C}_{2} \cdot$ rand. $\left(\right.$ Gbest $\left._{\mathrm{it}}-\mathrm{X}_{\mathrm{it}-1}\right)$

$\mathrm{X}_{\mathrm{it}}=\mathrm{X}_{\mathrm{it}-1}+\mathrm{V}_{\mathrm{it}}$

dimana $V_{i t}$ dan $X_{i t}$ adalah kecepatan dan posisi partikel saat ini, $V_{\text {it-1 }}$ dan $X_{\text {it-1 }}$ adalah kecepatan dan posisi partikel iterasi sebelumnya, Pbest ${ }_{i t}$ adalah posisi terbaik partikel, Gbest ${ }_{i t}$ adalah posisi terbaik dari seluruh partikel, $\mathrm{C}_{1}$ dan $\mathrm{C}_{2}$ adalah konstanta cognitive dan sosial acceleration, rand adalah nilai random yang terdistribusi dari $0-1$.

Pada tahun yang sama, R. Eberhart memperkenalkan algoritma lokal PSO. Prinsip dari teori lokal PSO adalah bahwa suatu partikel mengalami percepatan yang diakibatkan oleh partikel-partikel yang menjadi tetangga partikel yang bersangkutan, bukan diakibatkan oleh Gbest (posisi terbaik dari seluruh partikel). Sehingga persamaan update rulenya:

$\mathrm{V}_{\mathrm{it}}=\mathrm{V}_{\mathrm{it}-1}+\mathrm{C}_{1}$.rand. $\left(\right.$ Pbest $\left._{\mathrm{it}}-\mathrm{X}_{\mathrm{it}-1}\right)+\mathrm{C}_{2} \cdot$ rand.(Lbest $\left.{ }_{\mathrm{it}}-\mathrm{X}_{\mathrm{it}-1}\right)$

$\mathrm{X}_{\mathrm{it}}=\mathrm{X}_{\mathrm{it}-1}+\mathrm{V}_{\mathrm{it}}$

dimana $X_{i t}$ dan $V_{i t}$ adalah posisi dan kecepatan partikel saat ini, $\mathrm{X}_{\mathrm{it}-1}$ dan $\mathrm{V}_{\mathrm{it}-1}$ adalah posisi dan kecepatan partikel iterasi sebelumnya, Pbest ${ }_{i t}$ adalah posisi terbaik dari partikel, Lbest $_{i t}$ adalah posisi terbaik yang pernah dicapai oleh tetanggatetangga dari suatu partikel, $\mathrm{C}_{1}$ dan $\mathrm{C}_{2}$ adalah konstanta cognitive dan sosial acceleration, rand adalah nilai random yang terdistribusi dari $0-1$.

Perbedaan kedua metode PSO ini adalah dengan metode $\mathrm{J}$. Kennedy akan menghasilkan nilai optimasi yang konvergen dalam waktu yang sangat cepat namun dengan hasil yang kurang baik karena menggunakan Gbest sebagai dasar acuan pencarian posisi terbaiknya sedangkan metode R. Eberhart akan menghasilkan konvergensi nilai optimasi yang lebih lambat namun dengan hasil performa yang lebih baik.

\section{B. Adaptive Particle Swarm Optimization (APSO)}

Salah satu metode adaptive PSO yang dapat digunakan untuk optimasi adalah mengubah nilai inertia weight PSO setiap iterasinya [10]. Variasi ini merupakan pengembangan dari metode yang dikembangkan oleh J. Kennedy dan R. Eberhart. Dengan demikian inertia weight setiap iterasinya menjadi:

Wit $=W \max -W \min * \frac{(i t \max -i t) . i t}{i t \max }+W \min$

dimana Wmax dan Wmin adalah koefisien inertia weight maksimal dan minimal, it dan itmax adalah iterasi yang sedang berlangsung dan nilai maksimal dari iterasi yang digunakan, Wit adalah inertia weight pada iterasi saat ini. Persamaan kecepatan partikel setiap iterasinya menjadi:
$\mathrm{V}_{\mathrm{it}}=\mathrm{W} \cdot \mathrm{V}_{\mathrm{it}-1}+\mathrm{C}_{1} \cdot$ rand. $\left(\right.$ Pbest $\left._{\mathrm{it}}-\mathrm{X}_{\mathrm{it}-1}\right)+\mathrm{C}_{2} \cdot$ rand. $\left(\right.$ Gbest $\left._{\mathrm{it}}-\mathrm{X}_{\mathrm{it}-1}\right)(23)$ dimana $\mathrm{V}_{\text {it }}$ dan $\mathrm{V}_{\text {it-1 }}$ adalah kecepatan partikel saat ini dan pada iterasi sebelumnya, $X_{i t-1}$ adalah posisi partikel iterasi sebelumnya, Pbest ${ }_{i t}$ adalah posisi terbaik dari partikel, Gbest $_{i t}$ adalah posisi terbaik dari seluruh partikel, $\mathrm{C}_{1}$ dan $\mathrm{C}_{2}$ adalah konstanta cognitive dan sosial acceleration, rand adalah nilai random yang terdistribusi dari $0-1$.

Selain itu dengan besarnya nilai konstanta cognitive dan kecilnya nilai konstanta social di saat awal iterasi memungkinkan partikel untuk bergerak di sekitar ruang pencarian, sehingga tidak langsung bergerak menuju populasi terbaik secara prematur. Selama tahap optimasi selanjutnya, semakin kecilnya nilai konstanta cognitive dan semakin besarnya nilai konstanta social memungkinkan partikel untuk menuju ke suatu titik global optimum [11]. Sehingga konstanta akselerasi berubah secara adaptive seiring dengan bertambahnya iterasi menjadi:

$C_{1}=\left(C_{1}{ }^{\text {final }}-C_{1}{ }^{\text {initial }}\right)\left(\frac{\text { iter }}{\text { iter }_{\text {max }}}\right)+C_{1}{ }^{\text {initial }}, \mathrm{C}_{1}{ }^{\text {final }}<\mathrm{C}_{1}{ }^{\text {initial }}$

$C_{2}=\left(C_{2}{ }^{\text {final }}-C_{2}{ }^{\text {initial }}\right)\left(\frac{{ }^{\text {iter }}}{\text { iter }_{\max }}\right)+C_{2}{ }^{\text {initial }}, \mathrm{C}_{2}{ }^{\text {final }}>\mathrm{C}_{2}{ }^{\text {initial }}$

dimana $\mathrm{C}_{1}$ dan $\mathrm{C}_{2}$ adalah konstanta cognitive dan konstanta sosial acceleration, $\mathrm{C}_{1}{ }^{\text {final }}$ dan $\mathrm{C}_{1}{ }^{\text {initial }}$ adalah konstanta cognitive akhir dan awal, $\mathrm{C}_{2}{ }^{\text {final }}$ dan $\mathrm{C}_{2}{ }^{\text {initial }}$ adalah konstanta sosial acceleration akhir dan awal, iter dan iter $_{\max }$ adalah iterasi yang sedang berlangsung dan nilai maksimal dari iterasi yang digunakan.

\section{Implementasi dari Algoritma}

Alur algoritma yang digunakan untuk mengoperasikan sistem kelistrikan microgrid model islanded secara optimal tersebut adalah sebagai berikut:

1. Inisiasi parameter, rating daya, biaya bahan bakar dari setiap pembangkit berbahan bakar.

2. Daya keluaran dari pembangkit sel surya dan turbin angin dihitung sesuai kondisi dari radiasi matahari, temperatur suhu aktual dan kecepatan angin aktual.

3. Diasumsikan bahwa pembangkit sel surya dan turbin angin tidak membutuhkan biaya saat beroperasi.

4. Jika total permintaan beban lebih kecil dari daya keluaran sel surya dan turbin angin maka kebutuhan beban hanya akan dipenuhi oleh pembangkit energi baru-terbarukan dan jika ada daya pembangkitan lebih dari pembangkit energi baru-terbarukan maka daya lebih tersebut akan disimpan di dalam baterai (energy storage).

5. Jika total permintaan beban lebih besar daya keluaran sel surya dan turbin angin namun masih dapat disuplai jika ditambah dengan daya dari baterai, maka permintaan beban akan disuplai oleh daya keluaran sel surya, turbin angin dan ditambah dengan daya dari baterai.

6. Beban netto untuk dioptimasi menggunakan ED dihitung hanya jika daya keluaran dari pembangkit sel surya, turbin angin dan baterai lebih kecil dari permintaan beban sistem.

7. Beban netto yang dioptimasi dihitung berdasarkan beban total permintaan dikurangi dengan beban yang dapat disuplai oleh pembangkit sel surya dan turbin angin (pembangkit energi baru-terbarukan). 
8. Beban netto disuplai oleh pembangkit berbahan bakar dan baterai yang kemudian pembagian beban per pembangkitnya ditentukan berdasarkan optimasi ED.

Alur algoritma dapat dilihat pada gambar 3 berikut:

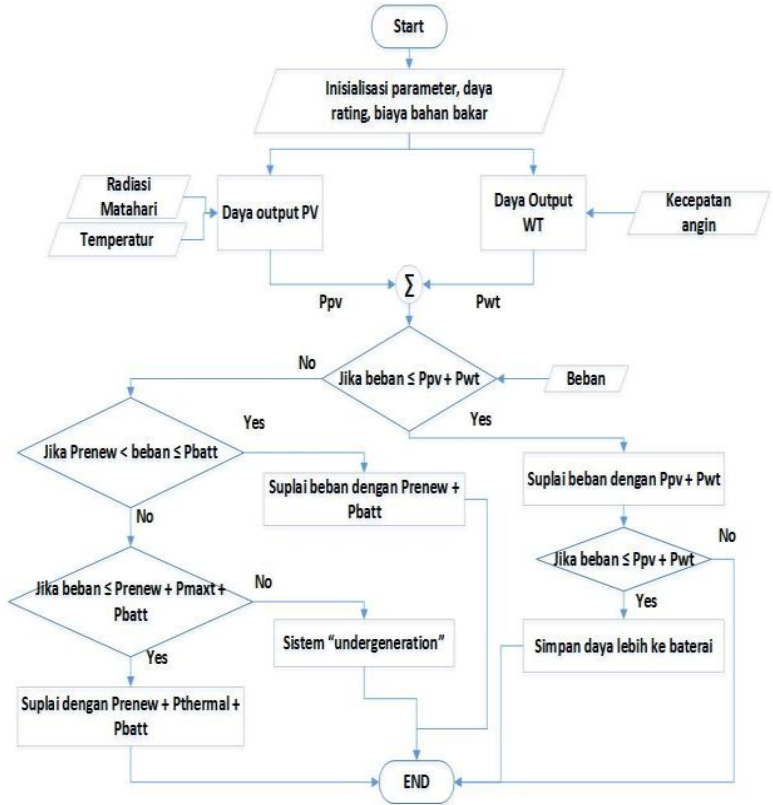

Gambar 3. Diagram Alir Algoritma Economic Dispatch Islanded Microgrid V.SIMULASI DAN ANALISIS

\section{A. Studi Kasus 1}

Pada studi kasus 1 total permintaan beban lebih kecil dari daya keluaran pembangkit sel surya dan pembangkit turbin angin sehingga akan ada daya sisa pembangkitan yang akan disimpan ke dalam baterai.

Tabel 2.

Data Masukan Studi Kasus 1

\begin{tabular}{ccccccc}
\hline \hline $\begin{array}{c}\text { Ka- } \\
\text { sus }\end{array}$ & $\begin{array}{c}\text { Total } \\
\begin{array}{c}\text { Beban } \\
(\mathrm{kW})\end{array}\end{array}$ & $\begin{array}{c}\text { Kecepatan } \\
\text { Angin }(\mathrm{m} / \mathrm{s})\end{array}$ & $\begin{array}{c}\text { Jumlah } \\
\text { Turbin } \\
\text { Angin } \\
(\text { unit })\end{array}$ & $\begin{array}{c}\text { Radiasi } \\
\text { Matahari } \\
(\mathrm{W} / \mathrm{m} 2)\end{array}$ & $\begin{array}{c}\text { Suhu } \\
\left({ }^{\circ} \mathrm{C}\right)\end{array}$ & $\begin{array}{c}\text { Jumlah } \\
\text { Sel Surya } \\
(\text { modul) }\end{array}$ \\
\hline 1 & 35 & 10 & 2 & 1000 & 30 & 302 \\
2 & 20 & 10 & 2 & 1000 & 30 & 302 \\
3 & 20 & 8 & 2 & 600 & 50 & 302 \\
4 & 25 & 12 & 2 & 800 & 30 & 302 \\
\hline \hline
\end{tabular}

Hasil simulasi pada studi kasus ini adalah:

Tabel 3.

Hasil Simulasi Studi Kasus 1

\begin{tabular}{ccccc}
\hline \hline Kasus & $\begin{array}{c}\text { Daya Sel } \\
\text { Surya }(\mathrm{kW})\end{array}$ & $\begin{array}{c}\text { Daya Turbin } \\
\text { Angin }(\mathrm{kW})\end{array}$ & $\begin{array}{c}\text { Total Daya } \\
\text { Renewable } \\
(\mathrm{kW})\end{array}$ & $\begin{array}{c}\text { Total Energi } \\
\text { Tersimpan }(\mathrm{kW})\end{array}$ \\
\hline 1 & 24.44 & 10.56 & 35 & 22.07 \\
2 & 20 & 0 & 20 & 37.07 \\
3 & 13.16 & 6.84 & 20 & 13.37 \\
4 & 19.55 & 5.45 & 25 & 38.55 \\
\hline \hline
\end{tabular}

Sehingga dapat terlihat perbedaan daya yang dibangkitkan oleh pembangkit sel surya dan turbin angin ketika mendapatkan nilai masukan yang bervariasi. Berbagai variasi total beban disimulasikan untuk mengetahui berapa sisa daya terbangkit yang mampu disimpan ke dalam energy storage.

\section{B. Studi Kasus 2}

Total permintaan beban lebih besar dari total daya keluaran pembangkit sel surya dan turbin angin sehingga dibutuhkan pembangkit berbahan bakar untuk memenuhi permintaan beban. Pada studi kasus ini juga digunakan baterai pada sistem. APSO digunakan untuk menentukan daya pembangkitan yang optimal untuk masing-masing pembangkit tersebut. Pada APSO ini diterapkan jumlah iterasi sebanyak 25 kali dan jumlah partikel sebanyak 15 . Untuk mengetahui perbedaan daya yang dibangkitkan oleh pembangkit maka data masukan pembangkit baru-terbarukan disamakan seperti pada tabel 4 berikut ini:

Tabel 4.

Data Masukan Studi Kasus 2

\begin{tabular}{ccccccc}
\hline \hline $\begin{array}{c}\text { Ka- } \\
\text { sus }\end{array}$ & $\begin{array}{c}\text { Total } \\
\text { Beban } \\
(\mathrm{kW})\end{array}$ & $\begin{array}{c}\text { Kecepatan } \\
\text { Angin }(\mathrm{m} / \mathrm{s})\end{array}$ & $\begin{array}{c}\text { Jumlah } \\
\text { Turbin } \\
\text { Angin } \\
(\text { unit })\end{array}$ & $\begin{array}{c}\text { Radiasi } \\
\text { Matahari } \\
\left(\mathrm{W} / \mathrm{m}^{2}\right)\end{array}$ & $\begin{array}{c}\text { Suhu } \\
\left({ }^{\circ} \mathrm{C}\right)\end{array}$ & $\begin{array}{c}\text { Jumlah } \\
\text { Sel Surya } \\
\text { (modul) }\end{array}$ \\
\hline 1 & 77 & 10 & 2 & 1000 & 30 & 302 \\
2 & 125 & 10 & 2 & 1000 & 30 & 302 \\
3 & 138 & 10 & 2 & 1000 & 30 & 302 \\
4 & 148 & 10 & 2 & 1000 & 30 & 302 \\
5 & 158 & 10 & 2 & 1000 & 30 & 302 \\
\hline
\end{tabular}

Hasil simulasi pola pengoperasian dari setiap pembangkit pada studi kasus ini dapat dilihat pada tabel 5 berikut ini:

Tabel 5.

Hasil Simulasi Daya Terbangkitkan dan Biaya Studi Kasus 2

\begin{tabular}{cccccccc}
\hline \hline \multirow{2}{*}{$\begin{array}{c}\text { Ka- } \\
\text { sus }\end{array}$} & $\begin{array}{c}\text { Sel } \\
\text { Surya }\end{array}$ & $\begin{array}{c}\text { Turbin } \\
\text { Angin }\end{array}$ & $\begin{array}{c}\text { Daya Pembangkitan }(\mathrm{kW} / \mathrm{h}) \\
\text { Bahan } \\
\text { Bakar }\end{array}$ & $\begin{array}{l}\text { Turbin } \\
\text { Mikro }\end{array}$ & $\begin{array}{c}\text { Generator } \\
\text { Diesel }\end{array}$ & $\begin{array}{c}\text { Bate- } \\
\text { rai }\end{array}$ & $\begin{array}{c}\text { Total } \\
\text { Biaya } \\
\text { Operasi } \\
(\mathrm{\epsilon} / \mathrm{h})\end{array}$ \\
\hline 1 & 24.44 & 32.63 & - & - & - & 19.93 & 0.08 \\
2 & 24.44 & 16.32 & 5 & 5 & 27.93 & 30 & 1624.62 \\
3 & 24.44 & 32.63 & 5 & 5 & 40.93 & 30 & 2153.57 \\
4 & 24.44 & 32.63 & 5.93 & 5 & 50 & 30 & 2566.57 \\
5 & 24.44 & 32.63 & 15.93 & 5 & 50 & 30 & 3018.76 \\
\hline \hline
\end{tabular}

Sehingga dapat terlihat perbedaan daya yang dibangkitkan oleh pembangkit berbahan bakar dan baterai. Pengoperasian baterai menjadi prioritas utama dibandingkan dengan pembangkit berbahan bakar. Setelah penggunaan baterai, pengoperasian pembangkit generator diesel mendapat prioritas pengoperasian karena memiliki biaya operasi lebih murah dibandingkan dengan pembangkit berbahan bakar yang lainnya.

\section{Studi Kasus 3}

Pada studi kasus 3 total permintaan beban lebih besar dari total daya keluaran pembangkit sel surya dan pembangkit turbin angin sehingga dibutuhkan pembangkit berbahan bakar untuk memenuhi total permintaan beban. Berbeda dengan studi kasus 2, pada studi kasus ini tidak digunakan baterai pada sistem. APSO digunakan untuk menentukan daya pembangkitan yang optimal untuk masing-masing pembangkit berbahan bakar tersebut. Pada APSO ini diterapkan jumlah iterasi sebanyak 25 kali dengan jumlah partikel sebanyak 15 . Untuk mengetahui perbedaan daya yang dibangkitkan oleh pembangkit berbahan bakar dan baterai maka data masukan pembangkit baru-terbarukan disamakan seperti pada tabel 6 berikut ini:

Tabel 6.

Data Masukan Studi Kasus 3

\begin{tabular}{ccccccc}
\hline \hline $\begin{array}{c}\text { Ka- } \\
\text { sus }\end{array}$ & $\begin{array}{c}\text { Total } \\
\text { Beban } \\
(\mathrm{kW})\end{array}$ & $\begin{array}{c}\text { Kecepatan } \\
\text { Angin }(\mathrm{m} / \mathrm{s})\end{array}$ & $\begin{array}{c}\text { Jumlah } \\
\text { Turbin } \\
\text { Angin } \\
(\text { unit })\end{array}$ & $\begin{array}{c}\text { Radiasi } \\
\text { Matahari } \\
\left(\mathrm{W} / \mathrm{m}^{2}\right)\end{array}$ & $\begin{array}{c}\text { Suhu } \\
\left({ }^{\circ} \mathrm{C}\right)\end{array}$ & $\begin{array}{c}\text { Jumlah } \\
\text { Sel Surya } \\
(\text { modul })\end{array}$ \\
\hline 1 & 77 & 10 & 2 & 1000 & 30 & 302 \\
2 & 125 & 10 & 2 & 1000 & 30 & 302 \\
3 & 138 & 10 & 2 & 1000 & 30 & 302 \\
4 & 148 & 10 & 2 & 1000 & 30 & 302 \\
5 & 158 & 10 & 2 & 1000 & 30 & 302 \\
\hline \hline
\end{tabular}

Beban yang digunakan pada studi kasus ini bervariasi sehingga didapatkan pola pengoperasian dari pembangkit yang berbeda-beda dan dapat dilihat pada tabel 7 berikut ini:

Tabel 7.

Hasil Simulasi Daya Terbangkitkan dan Biaya Studi Kasus 3

\begin{tabular}{|c|c|c|c|c|c|c|}
\hline \multirow[b]{3}{*}{ Kasus } & \multicolumn{5}{|c|}{ Daya Pembangkitan $(\mathrm{kW} / \mathrm{h})$} & \multirow{2}{*}{$\begin{array}{l}\text { Total } \\
\text { Biaya }\end{array}$} \\
\hline & Sel & Turbin & Sel Bahan & Turbin & Generator & \\
\hline & Surya & Angin & Bakar & Mikro & Diesel & $\begin{array}{c}\text { Operasi } \\
(€ / \mathrm{h})\end{array}$ \\
\hline 1 & 24.44 & 32.63 & 5 & 5 & 9.93 & 897.69 \\
\hline
\end{tabular}




\begin{tabular}{lllcccc}
\hline \hline 2 & 24.44 & 32.63 & 12.93 & 5 & 50 & 2882.78 \\
3 & 24.44 & 32.63 & 25 & 5.93 & 50 & 3475.25 \\
4 & 24.44 & 32.63 & 25 & 15.93 & 50 & 3957.43 \\
5 & 24.44 & 32.63 & 25 & 25.93 & 50 & 4441.62 \\
\hline \hline
\end{tabular}

Sehingga dapat terlihat perbedaan daya yang dibangkitkan oleh pembangkit berbahan bakar. Pengoperasian pembangkit generator diesel mendapat prioritas pengoperasian karena memiliki biaya operasi lebih murah dibandingkan dengan pembangkit berbahan bakar yang lainnya. Sedangkan pembangkit turbin mikro mendapatkan prioritas terakhir dalam pengoperasiannya karena memiliki biaya operasi yang paling mahal. Parameter beban yang digunakan pada studi kasus 3 ini disamakan dengan studi kasus 2 sehingga dapat terlihat perbedaan total biaya operasi yang dikeluarkan untuk memenuhi kebutuhan daya sistem.

Tabel 8.

Hasil Simulasi Perbandingan Biaya Operasi

\begin{tabular}{cccccc}
\multicolumn{5}{c}{ Hasil Simulasi Perbandingan Biaya Operasi } \\
\hline \hline \multicolumn{5}{c}{ Total Biaya Operasi (€/h) } \\
\hline $\begin{array}{c}\text { Menggunakan } \\
\text { energy } \\
\text { storage } \\
\begin{array}{c}\text { Tanpa energy } \\
\text { storage }\end{array}\end{array}$ & 0.08 & $125 \mathrm{~kW}$ & $138 \mathrm{~kW}$ & $148 \mathrm{~kW}$ & $158 \mathrm{~kW}$ \\
\hline \hline
\end{tabular}

Berdasarkan dari kelima kasus variasi beban yang telah disimulasikan, dapat terlihat jika menggunakan baterai (energy storage) dalam sistem akan berpengaruh pada penghematan biaya operasi untuk pemenuhan kebutuhan sistem jika dibandingkan tanpa menggunakan baterai.

\section{D.Studi Kasus 4}

Pada studi kasus 4 ini dilakukan perbandingan hasil dari metode APSO dengan metode quadratic programming. Perbandingan ini dilakukan dengan memasukkan nilai beban yang berubah-berubah dengan kondisi data masukan pembangkit baru-terbarukan disamakan seperti pada tabel 9: Tabel 9.

Data Masukan Studi Kasus 4

\begin{tabular}{ccccccc}
\hline \hline $\begin{array}{c}\text { Ka- } \\
\text { sus }\end{array}$ & $\begin{array}{c}\text { Total } \\
\text { Beban } \\
(\mathrm{kW})\end{array}$ & $\begin{array}{c}\text { Kecepatan } \\
\text { Angin }(\mathrm{m} / \mathrm{s})\end{array}$ & $\begin{array}{c}\text { Jumlah } \\
\text { Turbin } \\
\text { Angin } \\
(\text { unit })\end{array}$ & $\begin{array}{c}\text { Radiasi } \\
\text { Matahari } \\
\left(\mathrm{W} / \mathrm{m}^{2}\right)\end{array}$ & $\begin{array}{c}\text { Suhu } \\
\left({ }^{\circ} \mathrm{C}\right)\end{array}$ & $\begin{array}{c}\text { Jumlah } \\
\text { Sel Surya } \\
\text { (modul) }\end{array}$ \\
\hline 1 & 40 & 10 & 2 & 1000 & 30 & 302 \\
2 & 84 & 10 & 2 & 1000 & 30 & 302 \\
3 & 175 & 10 & 2 & 1000 & 30 & 302 \\
\hline \hline
\end{tabular}

Beban yang digunakan pada studi kasus ini bervariasi sehingga didapatkan pola pengoperasian dari pembangkit berbahan bakar yang berbeda-beda. Data masukan studi kasus ini juga digunakan pada kedua metode untuk mendapatkan perbandingan hasil dari kedua metode tersebut. Hasil simulasi percobaan dengan menggunakan metode APSO dapat dilihat pada tabel 10. Sedangkan hasil simulasi percobaan dengan menggunakan metode QP dapat dilihat pada tabel 11.

Tabel 10.

Hasil Simulasi Daya Terbangkitkan, Biaya Operasi dan Waktu yang Dibutuhkan Studi Kasus 4 APSO

\begin{tabular}{|c|c|c|c|c|c|c|c|c|}
\hline \multirow[b]{2}{*}{$\begin{array}{l}\text { Ka- } \\
\text { sus }\end{array}$} & \multicolumn{6}{|c|}{ 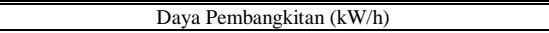 } & \multicolumn{2}{|c|}{$\begin{array}{c}\text { Biaya Operasi } \\
(\in / \mathrm{h})\end{array}$} \\
\hline & $\begin{array}{c}\text { Sel } \\
\text { Sur } \\
\text { ya }\end{array}$ & $\begin{array}{l}\text { Turbin } \\
\text { Angin }\end{array}$ & $\begin{array}{c}\text { Sel } \\
\text { Bahan } \\
\text { Bakar }\end{array}$ & $\begin{array}{l}\text { Turbin } \\
\text { Mikro }\end{array}$ & $\begin{array}{c}\text { Gene- } \\
\text { rator } \\
\text { Diesel }\end{array}$ & $\begin{array}{c}\text { Bate- } \\
\text { rai }\end{array}$ & ( & 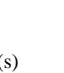 \\
\hline 1 & $\begin{array}{c}24.4 \\
4\end{array}$ & 32.63 & - & - & - & $\begin{array}{c}+19.9 \\
3\end{array}$ & - & $\begin{array}{c}0.0055 \\
2\end{array}$ \\
\hline 2 & $\begin{array}{c}24.4 \\
4\end{array}$ & 16.32 & - & - & - & $\begin{array}{c}- \\
26.93\end{array}$ & 0.10 & $\begin{array}{c}0.0043 \\
2\end{array}$ \\
\hline 3 & $\begin{array}{c}24.4 \\
4\end{array}$ & 32.63 & 25 & 12.93 & 50 & -30 & 3812.68 & $\begin{array}{c}0.1780 \\
8\end{array}$ \\
\hline
\end{tabular}

Tabel 11.

Hasil Simulasi Daya Terbangkitkan, Biaya Operasi dan Waktu yang Dibutuhkan Studi Kasus 4 QP

\begin{tabular}{|c|c|c|c|c|c|c|c|c|}
\hline \multirow[b]{2}{*}{$\begin{array}{l}\text { Ka- } \\
\text { sus }\end{array}$} & \multicolumn{6}{|c|}{ Daya Pembangkitan $(\mathrm{kW} / \mathrm{h})$} & \multirow{2}{*}{$\begin{array}{c}\text { Biaya } \\
\text { Operasi } \\
(€ / \mathrm{h})\end{array}$} & \multirow[b]{2}{*}{$\begin{array}{l}\text { Waktu } \\
\text { (s) }\end{array}$} \\
\hline & $\begin{array}{c}\text { Sel } \\
\text { Sury }\end{array}$ & $\begin{array}{l}\text { Turbin } \\
\text { Angin }\end{array}$ & $\begin{array}{c}\text { Sel } \\
\text { Bahan }\end{array}$ & $\begin{array}{l}\text { Turbin } \\
\text { Mikro }\end{array}$ & $\begin{array}{l}\text { Gene- } \\
\text { rator }\end{array}$ & $\begin{array}{c}\text { Bate- } \\
\text { rai }\end{array}$ & & \\
\hline
\end{tabular}

\begin{tabular}{ccccccccc}
\hline & $\mathrm{a}$ & & Bakar & \multicolumn{7}{c}{ Diesel } \\
\hline 1 & 24.4 & 32.63 & - & - & - & +19.9 & - & 0.0058 \\
& 3 & & & & & 3 & & 8 \\
2 & 24.4 & 16.32 & - & - & - & - & 0.10 & 0.0054 \\
& 4 & & & & & 26.93 & & 1 \\
3 & 24.4 & 32.63 & 25 & 12.93 & 50 & -30 & 3812.68 & 0.2603 \\
& 4 & & & & & & & 4
\end{tabular}

Sehingga dapat terlihat bahwa metode APSO maupun metode QP dapat menghasilkan nilai optimasi pembagian beban dan biaya operai yang sama pada setiap pembangkit. Sehingga untuk membandingkan dapat ditinjau dari aspek lain yakni dimana berdasarkan hasil simulasi tersebut APSO memiliki kemampuan untuk mencari nilai optimum dalam waktu yang rata-rata lebih singkat, namun jumlah iterasi dan partikel pada metode APSO harus disesuaikan berdasarkan kompleksitas dari kasus yang ingin dioptimasi untuk mendapatkan hasil optimum yang konvergen pada setiap kali percobaan.

\section{E. Studi Kasus 5}

Pada studi kasus 5 ini dilakukan perbandingan metode PSO dengan metode APSO. Perbandingan ini dilakukan pada nilai beban $125 \mathrm{~kW}$. Percobaan dilakukan sebanyak 4 kali untuk masing-masing metode seperti pada tabel 12 berikut:

Tabel 12.

Hasil Simulasi PSO dan APSO

\begin{tabular}{ccccccccc}
\hline \hline & \multicolumn{3}{c}{ PSO } & \multicolumn{4}{c}{ APSO } \\
\cline { 2 - 8 } & \multicolumn{3}{c}{ Percobaan ke- } & \multicolumn{4}{c}{ Percobaan ke- } \\
\cline { 2 - 9 } & 1 & 2 & 3 & 4 & 1 & 2 & 3 & 4 \\
Konvergensi & 20 & 19 & 11 & 12 & 8 & 10 & 9 & 7 \\
iterasi ke- & & & & & & & & \\
\hline \hline
\end{tabular}

Adapun grafik konvergensi PSO dan APSO pada percobaan ke-4 dapat dilihat pada gambar 4 dan gambar 5:

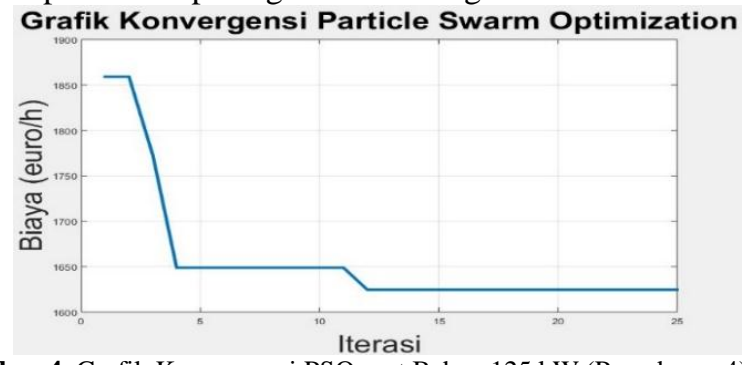

Gambar 4. Grafik Konvergensi PSO saat Beban 125 kW (Percobaan 4) Grafik Konvergensi Adaptive Particle Swarm Optimization

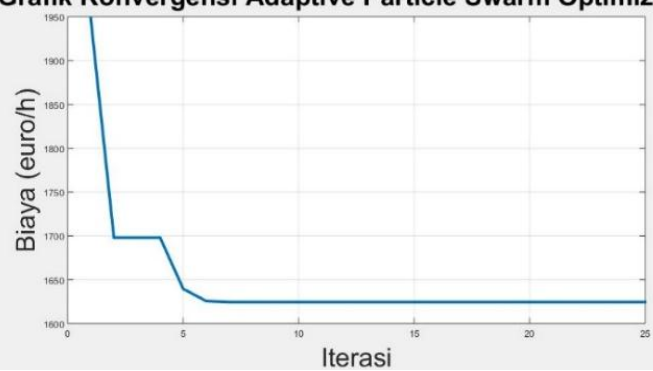

Gambar 5. Grafik Konvergensi APSO saat Beban 125 kW (Percobaan 4)

Sehingga dapat terlihat bahwa metode APSO mencapai nilai konvergensi lebih cepat dibandingkan dengan metode PSO. Dengan demikian, metode APSO yang digunakan pada penelitian ini memiliki efisiensi yang lebih baik.

\section{KESIMPULAN}

Berdasarkan hasil analisis penelitian dari aplikasi ED pada sistem kelistrikan microgrid dengan energy storage 
menggunakan APSO, dapat diambil kesimpulan sebagai berikut:

1. Penerapan algoritma APSO pada kasus ED mampu menentukan berapa besarnya daya yang dibangkitkan oleh setiap pembangkit yang ada berdasarkan permintaan beban dalam sistem kelistrikan microgrid. Sehingga kebutuhan beban dalam sistem dapat terpenuhi dengan biaya yang paling minimum.

2. Penggunaan energy storage dalam sistem kelistrikan microgrid memberikan pengaruh penghematan biaya operasi total jika dibandingkan dengan tanpa menggunakan energy storage.

3. Algortima APSO mampu mencapai nilai optimum pada nilai iterasi yang lebih singkat untuk mencapai nilai konvergensinya daripada algoritma PSO.

\section{DAFTAR PUSTAKA}

[1] Pathom Attaviriyanupap, Student Member, IEEE, Hiroyuki Kita, Eiichi Tanaka, and Jun Hagewa, Member, IEEE. "A Hybrid EP and SQP for Dynamic Economic Dispatch With Nonsmooth Fuel Cost Function", IEEE Trans. On Power Systems, Vol. 17, No. 2, May 2002.

[2] Hatziargyriou, N. (2013). Microgrids: Architectures and Control, John Wiley \& Sons. BELUM

[3] de Souza Ribeiro, L., Saavedra, O., de Lima, S. and Gomes de Matos, J. (2011). Isolated microgrids with renewable hybrid generation: The case of lencois island, Sustainable Energy, IEEE Transactions on 2(1): 1-11.

[4] D.W. Ross, S. Kim, "Dynamic Economic Dispatch of Generation", IEEE Trans. On Power Apparatus and Systems, vol. PAS-99, no. 6, pp. 20602068, Nov. 1980.

[5] X. S. Han, H. B. Gooi, D. S. Kirschen, "Dynamic Economic Dispatch: Feasible and Optimal Solutions", IEEE Trans. On Power Systems, vol. 16, no.1, pp. 22-28, Feb.2001.

[6] Mohammed Faisal A, Koivo Heikki., "System modelling and online optimal management of MicroGrid using Mesh Adaptive Direct Search", International Journal of Electrical Power \& Energy Systems., Vol. 32, no 5. 2010, pp. 398-407. BELUM

[7] Logenthiran, T. and Srinivasan, D. (2009). "Short term generation scheduling of a microgrid", TENCON 2009-2009 IEEE Region 10 Conference, IEEE, pp. 1-6.

[8] Modiri-Delshad, M., Koohi-Kamali, S., Taslimi, E., Kaboli, A., Hr, S. and Rahim, N. (2013). "Economic dispatch in a microgrid through an iterated-based algorithm", Clean Energy and Technology (CEAT), 2013 IEEE Conference on, IEEE, pp. 82-87.

[9] J. Kennedy and R. Eberhart, "Particle Swarm Optimization", In IEEE Int. Conf on Neural Networks, Perth, Australia, 1942-1948, 1995.

[10] Y. Shi, R. Eberhart, "Empirical Study of particle swarm optimization", In Proceedings of the 1999 IEEE Congress on Evolutionary Computation, Piscatawaym, NJ, IEEE Press, pp 1945-1950, 1999.

[11] K.T. Chaturvedi, M. Pandit, L. Srivastava, "Self-organizing hierarchical particel swarm optimization for nonconvex economic dispatch", IEEE Trans. Power Syst. 23 (3) (2008) 1079-1087.

[12] Xiaoping Liu, Ming Ding, Jianghong Han, Pingping Han and Yali Peng, "Dynamic Economic Dispatch for Microgrids Including Battery Energy Storage", 2nd IEEE International Symposium on Power Electronics for Distributed Generation Systems, 2010.

[13] Deckmyn Christof, L. Vandoorn Tine, Moradzades Mohammad and Vandevelde Lieven, "Multi-objective optimization for environomic scheduling in microgrids", 2014.

[14] Amjady Nima, Rezai Soleymanpour Hassan, "Daily Hydrothermal Generation Scheduling by a new Modified Adaptive Particle Swarm Optimization technique", 2009.

[15] ReDriven $20 \mathrm{~kW}$, ReDriven Power Inc. 